\title{
SISTEM INFORMASI PENGOLAHAN DATA GAJI KARYAWAN PADA PT. BATIK DANARHADI BERBASIS MULTI USER
}

\author{
Muhammad Nashiruddin
}

PT. Batik Danarhadi Surakarta

\begin{abstract}
Along with the development of technology in this case increasingly rapid information technology, then motivated PT. Batik Danarhadi Surakarta to organize good management of the course of company activities, by applying computer applications. Due to this time the system used is still manual, especially in the financial section so in making reports on payroll reports in the financial section is very slow. On the other hand the leadership also had difficulty in checking and accessing the payroll report. So this study discusses issues in particular regarding the employee payroll system at PT. Batik Danarhadi Surakarta.

The purpose of the preparation of this final project can be expected to produce systems and applications that can be used to assist the finance department in handling employee payroll issues, so as to produce up to date information, while also making it easier for leaders to conduct checks and audits. The new system that will be made at PT. Batik Danarhadi Surakarta is a computerized employee payroll system, where this new system of database models used in the employee payroll application program is Database Access (*. Mdb) and the programming language used is Microsoft Visual Basic 6.0. In making this system using system design tools, namely: Document Flow Chart, Data Flow Diagrams (DAD), Input-Output Design, Database Design, Technology Design, Database Table Relations. The employee payroll application model that will be made consists of several processes including process data input, employee data input, attendance and overtime transactions, employee loan transactions, employee payroll transactions, job data reports, employee data reports, attendance and overtime reports, reports employee loans and employee payroll reports.
\end{abstract}

Keywords: Information system, Employee Payroll system, computerized

\section{Pendahuluan}

Teknologi komputer berkembang seiring dengan perkembangan teknologi yang semakin pesat dari tahun ke tahun. Komputer memiliki peranan penting dalam segala kegiatan. Hampir semua perusahaan maupun instansi memanfaatkan komputer sebagai sarana untuk menyajikan informasi yang dibutuhkan dan penting bagi perusahaan. Dipergunakannya komputer akan diperoleh laporan yang lebih cepat, tepat dan akurat daripada sistem manual. Komputer sebagai alat bantu pengolahan data, akan menjadikan semua kegiatan lebih efektif dan efisien. Mengurangi kemungkinan terjadinya kesalahan dalam pencatatan data, perhitungan bahkan dalam pemberian gaji bagi para karyawan. Begitu pula yang berlaku pada PT. Batik Danarhadi Surakarta yang pada awalnya pengerjaan pengolahan gaji karyawan masih dilakukan semi manual, sehingga dalam sistem kerjanya sulit, maka pada akhirnya waktu yang dibutuhkan untuk menyelesaikannya relatif lama. Untuk menangani sistem penggajian dibutuhkan suatu sistem yang tersusun rapi dan memberikan kemudahan, kecepatan dan ketepatan menyajikan informasi yang di 
butuhkan dalam menangani masalahmasalah yang berhubungan dengan sistem penggajian karyawan.

\section{Tinjauan Pustaka \\ Pengertian Sistem Informasi}

Pengertian sistem informasi menurut

Yogiyanto HM adalah: "Sistem informasi adalah sekumpulan elemen yang bekerja secara bersamasama baik secara manual ataupun berbasis komputer dalan melaksanakan pengolahan data yang berupa pengumpulan, penyimpanan, pemrosesan data untuk menghasilkan informasi yang bermakna dan berguna bagi

proses pengambilan keputusan". (Yogiyanto HM, Akt., MBA, Ph. D, 2001).

Sistem informasi bertujuan untuk menghasilkan informasi yang berkaitan langsung dengan proses pengambilan keputusan, baik bersifat semi terstruktur ataupun tidak terstruktur.

\section{Pengertian Data}

Data adalah segala sesuatu yang dapat diterima oleh indera manusia dari rangsangan-rangsangan yang ada disekitarnya baik secara tersurat maupun tersirat. Sedangkan pengertian data pada komputer, data adalah segala sesuatu yang dapat dikodekan atau disimbolkan atau dilambangkan dengan kode-kode, simbolsimbol, atau lambang-lambang yang telah disediakan di setiap computer

\section{Pengertian Pengolahan Data}

Pengolahan data adalah suatu kegiatan memproses suatu data, dimana data yang diolah masih berupa data mentah dengan melalui tahapan-tahapan proses sehingga menghasilkan informasi yang berguna bagi pihak yang bersangkutan, dan kegiatan tersebut memerlukan suatu alat bantu yang mendukung unutk menghasilkan hasil yang baik.

\section{Pengertian Gaji dan Karyawan}

Gaji menurut Undang-undang No. 8 Tahun 1974 BAB II pasal 7 tentang pokokpokok kepegawaian. "Setiap pegawai berhak memperoleh gaji layak sesuai dengan pekerjaan dan tanggung jawabnya”.
Karyawan adalah seseorang yang telah membuat sebuah ikatan kerja pada sebuah instansi atau perusahaan yang telah mengikatkan diri pada sebuah perjanjian kerja yang telah disetujui oleh kedua belah pihak.

Di PT. Batik Danarhadi ada beberapa penggolongan karyawan yaitu

1. Karyawan tetap adalah karyawan yang telah memenuhi persyaratan penerimaan karyawan seperti yang telah ditetapkan terikat pada hubungan kerja dengan perusahaan sampai dengan batas waktu pensiun serta sudah melampaui masa percobaan (disahkan dengan Surat Keputusan perusahaan).

2. Karyawan Kontrak adalah karyawan yang telah memenuhi persyaratan penerimaan karyawan seperti telah ditetapkan dan terikat pada hubungan kerja dengan perusahaan atas dasar kontrak kerja dan dalam jangka yang tertentu lamanya. Apabila hasil kerja dari karyawan kontrak tersebut

berjalan baik maka setelah habis masa kontrak dapat diajukan menjadi karyawan tetap.

\section{Pengertian Multi User}

"Multi User adalah dimana lebih dari satu orang dapat menggunakan program yang sama atau berbeda dari satu mesin yang sama pada saat bersamaan, diterminal yang sama atau berbeda" (WAHANA Komputer, 2001)

"Multi User adalah sistem operasi yang membiarkan banyak pengguna untuk masuk dan menggunakan sistem pada waktu yang bersamaan, masing-masing bisa melaksanakan pekerjaan mereka secara bebas tanpa tergantung pada pengguna yang lain". (http://www.ilmukomputer.com).

Kelebihan dari sistem Multi User adalah:

1. Menggunakan sistem Multi User yang memungkinkan penggunaan program secara bersama-sama (Local Area Network)

2. Program dapat dijalankan dari sistem DOS, Windows 3.11/95/98, dan jaringan

3. Bila di-install dari sistem Windows standar, program akan membuat shortcut folder pada desktop windows untuk mempermudah menjalankannya 
4. Dilengkapi dengan fungsi proteksi berupa fasilitas password pemakai beserta hak akses

\section{Metodologi Penelitian}

- Metode Pengumpulan Data Primer dilakukan agar dalam penelitian nantinya dapat diperoleh data-data yang memiliki relevansi. Teknik pengumpulan data adalah sebagai berikut:

1. Metode Observasi, mengamati secara langsung aktifitas yang berkaitan dengan sistem penggajian karyawan pada PT. Batik Danarhadi Surakarta yang sudah berjalan saaat ini, sehingga dapat mengetahui sistem kerjanya dan mempelajari bentuk-bentuk formulir input dan formilir output. Dari metode ini didapat beberapa formulir yang dibutuhkan untuk membuat aplikasi sistem penggajian karyawan pada PT. Batik Danarhadi yang meliputi: Formulir Data Karyawan, Kartu Presensi, Surat Perintah Kerja Lembur (SPKL), Blanko Pinjaman dan Slip Gaji.

2. Metode Wawancara (Interview)

Metode wawancara memungkinkan untuk mengumpulkan data secara bertatap muka dengan

yang diwawancarai (para user / pemakai). Metode ini dilakukan dengan cara wawancara dengan bagian-bagian yang terkait dengan aplikasi sistem penggajian karyawan yaitu Bagian Personalia dan Bagian Keuangan. Pada Bagian Personalia, pertanyaan yang diajukan proses pencatatan data karyawan dan proses pencatatan presensi dan lembur karyawan. Pada Bagian Keuangan, pertanyan yang diajukan proses pinjaman karyawan dan proses perhitungan gaji karyawan.

- Metode Pengumpulan Data Sekunder

Data sekunder yaitu data yang diperoleh dari studi kepustakaan dengan cara mengumpulkan dan mempelajari data / informasi serta pengetahuan yang berasal dari buku-buku, literatur, sebagainya yang berhubungan dengan masalah penggajian karyawan.

\section{- Analisa Data}

Analisis data yang digunakan meliputi pengkajian terhadap keseluruhan data yang ada pada

bagian keuangan mengenai sistem penggajian karyawan pada PT. Batik Danarhadi Surakarta.

\section{-Analisa Sistem Yang Berjalan}

Untuk mengetahui sistem yang ada saat ini pada PT. Batik Danarhadi Surakarta, khususnya Bagian Keuangan. Analisa sistem yang ada ini perlu dilakukan sebelum melakukan analisa permasalahan, kelemahan-kelemahan sistem dan kebutuhan sistem. Adapun permasalahan yang terjadi berdasarkan sistem yang digunakan pada PT. Batik Danarhadi Surakarta adalah pengolahan data penggajian karyawan yang masih menggunakan cara manual sehingga mengalami keterlambatan dalam hal proses transaksi dan proses laporan informasi data penggajian karyawan, maka dibuat sistem baru yang nantinya dapat mengatasi permasalahan yang terjadi, sehingga penerimaan laporan dapat diterima dengan cepat, tepat dan akurat.

Kebutuhan perangkat keras (Hardware) dan kebutuhan perangkat lunak (Software) yang akan digunakan pada sistem penggajian karyawan pada PT. Batik Danarhadi Surakarta adalah :

-Analisa Kebutuhan Perangkat Keras (Hardware)

Spesifikasi perangkat keras yang digunakan untuk membuat Sistem Informasi Pengolahan Data Gaji Karyawan pada PT. Batik Danarhadi Surakarta Berbasis Multi User adalah sebagai berikut: Prosessor Intel Core 2 Duo $2.4 \mathrm{GHz}$, MainBoard Type Gigabyte GA-945GCMS-2C LGA 775 Chipset Intel 945GC, DDRII KINGSTON 1 GB MB PC 530026, Piranti Simpanan Hard Disk Seagate SATA2 dengan kapasitas 160 GB, Piranti masukkan berupa Keyboard dan Mouse, Piranti keluaran berupa LCD Benq 15" dan Printer Epson LQ-2180 Dotmatrix.

-Analisa Kebutuhan Perangkat Lunak (Software) 
Perangkat lunak merupakan sekumpulan perintah untuk menjalankan perangkat keras.

Perangkat lunak terdiri dari sistem operasi dan bahasa pemrograman

aplikasi.Perangkat lunak yang digunakan untuk membuat dan mengoperasikan Sistem Informasi Pengolahan Data Gaji Karyawan ini

adalah: Sistem Operasi Windows XP Professional, Perangkat lunak Microsoft Visual Basic 6.0, Crystal Report 8.5.

\section{Perancangan Basis Data}

Perancangan basis data yang dilakukan adalah dalam bentuk pembuatan Diagram Alur Data yang telah disempurnakan setelah dilakukan analisa kebutuhan sistem dan perancangan sistem yang meliputi pembuatan Diagram Konteks (Context Diagram), Hirearchy Input Process Output (HIPO), Entity Relationship Diagram (ERD), Kamus Data (Data Dictionary), Desain Input dan Desain Output

\section{Perancangan Interface}

Pada tahap ini dilakukan perancangan bentuk interface program yang dibuat, dengan tujuan supaya pemakai mudah mengerti (user friendly). Perancangan interface ini meliputi perancangan laporanlaporan yang diinginkan serta menu-menu yang terdapat dalam program nantinya.

\section{Perancangan Program dan Implementasinya}

Perancangan program dan implementasi program yang sudah siap akan dilakukan pada tahap ini, dengan kriteria adalah program mudah dalam digunakan dan program mudah dipahami oleh pemakai. Perancangan program ini mengacu pada Diagram Alir Data yang telah kita buat pada langkah perancangan sistem. Pada tahap ini perlu dijelaskan mengenai pemakaian program pada calon operator.

\section{Hak Akses dan Matriks}

Aturan dan prosedur Multi User yang diterapkan pada sistem informasi pengolahan data penggajian karyawan pada PT. Batik Danarhadi Surakarta terbagi dari empat bagian yaitu Administrator, Manajer Keuangan, Bagian Personalia dan Bagian Keuangan, dimana masing-masing bagian mempunyai hak akses sendiri-sendiri, berikut ini hak akses yang dimilki setiap bagian dalam tabel 1:

Tabel 1. Matriks Hak Akses

\begin{tabular}{|c|c|c|c|c|c|}
\hline \multirow{2}{*}{ No } & \multirow{2}{*}{ Kegiatan } & \multicolumn{4}{|c|}{ Bagian Yang Terkait } \\
\hline & & Administrator & Manajer Keu. & Bag. Personalia & Bag. Keuangan \\
\hline 1. & Konfigurasi Sistem & RW & $\mathrm{F}$ & $\mathrm{F}$ & $\mathrm{F}$ \\
\hline 2. & Input Data User & RW & $\mathrm{F}$ & $\mathrm{F}$ & $\mathrm{F}$ \\
\hline 3. & Input Data Jabatan & RW & $\mathrm{F}$ & RW & $\mathrm{F}$ \\
\hline 4. & Input Data Karyawan & RW & $\mathrm{F}$ & RW & $\mathrm{F}$ \\
\hline 5. & Input Data Presensi \& Lembur & RW & $\mathrm{F}$ & RW & $\mathrm{F}$ \\
\hline 6. & Input Data Pinjaman & RW & $\mathrm{F}$ & $\mathrm{F}$ & RW \\
\hline 7. & Input Data Penggajian & RW & $\mathrm{F}$ & $\mathrm{F}$ & RW \\
\hline 8. & Lap. Data Jabatan & $\mathrm{R}$ & $\mathrm{R}$ & $\mathrm{R}$ & $\mathrm{F}$ \\
\hline 9. & Lap. Data Karyawan & $\mathrm{R}$ & $\mathrm{R}$ & $\mathrm{R}$ & $\mathrm{F}$ \\
\hline 10. & Lap. Data Presensi \& Lembur & $\mathrm{R}$ & $\mathrm{R}$ & $\mathrm{R}$ & $\mathrm{F}$ \\
\hline 11. & Lap. Data Pinjaman & $\mathrm{R}$ & $\mathrm{R}$ & $\mathrm{F}$ & $\mathrm{R}$ \\
\hline 12. & Lap. Data Penggajian & $\mathrm{R}$ & $\mathrm{R}$ & $\mathrm{F}$ & $\mathrm{R}$ \\
\hline 13. & Proses Reindex & RW & $\mathrm{F}$ & $\mathrm{F}$ & $\mathrm{F}$ \\
\hline 14. & Proses Back Up & RW & $\mathrm{F}$ & $\mathrm{F}$ & $\mathrm{F}$ \\
\hline 15. & Proses Tutup Buku & RW & $\mathrm{F}$ & $\mathrm{F}$ & $\mathrm{F}$ \\
\hline 16. & Proses Restore & RW & $\mathrm{F}$ & $\mathrm{F}$ & $\mathrm{F}$ \\
\hline
\end{tabular}

Keterangan : R : Read :Proses dapat diakses bagian yang terkait, tetapi bagian yang terkait tidak dapat melakukan pengolahan data.

RW : Read and Write: Proses dapat diakses dan bagian yang terkait dapat melakukan pengolahan data

F : False : Proses tidak dapat diakses bagian yang terkait karena proses mati (disabled). 


\section{Hasil dan Pembahasan}

\section{DiagramKonteks (Context Diagram)}

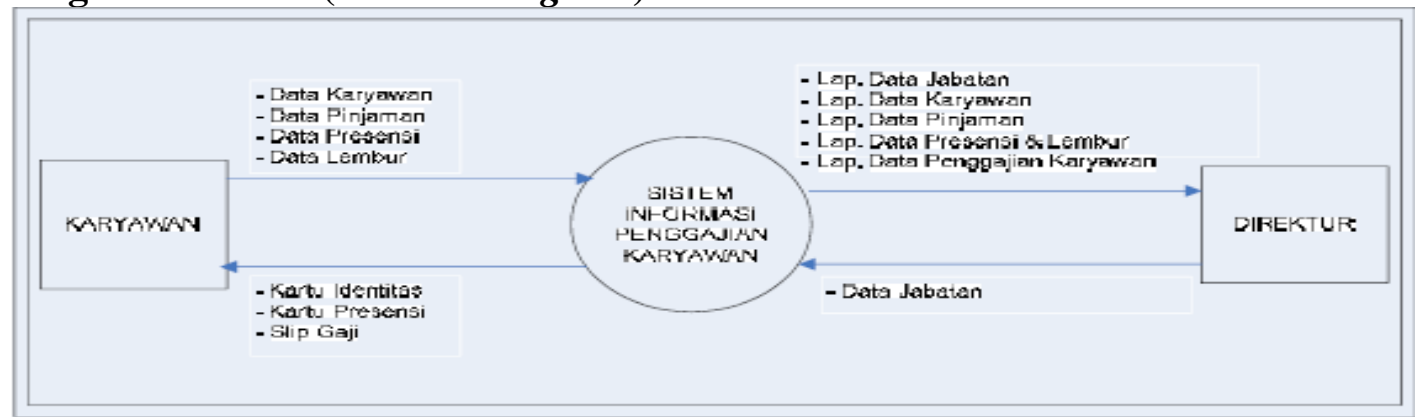

Gambar 1. Diagram Konteks DiagramKonteks (Context Diagram)

\section{Hierarchy Input Process Output Sistem Penggajian}

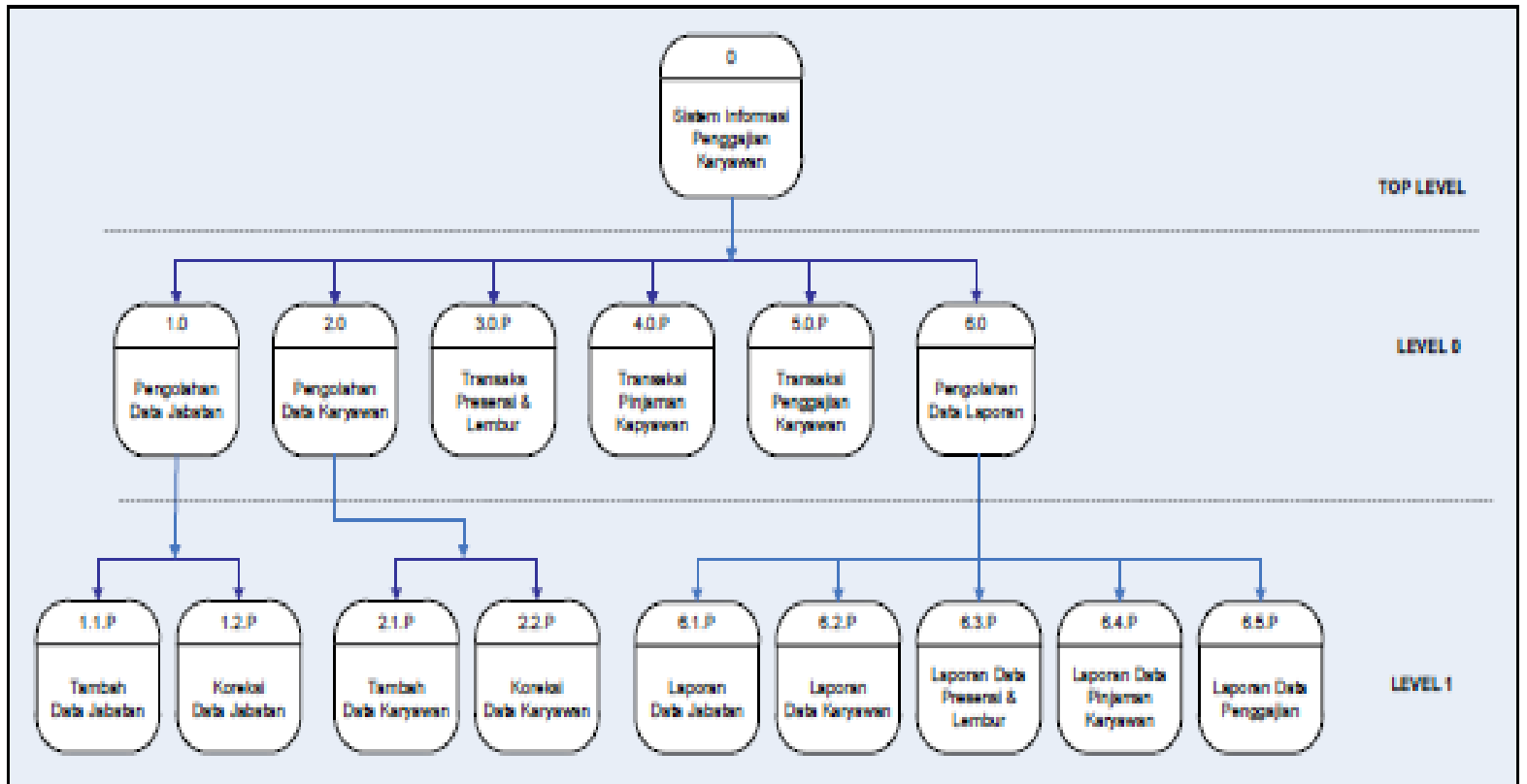

Gambar 2. Hierarchy Input Process Output (HIPO)

Diagram Arus Data (DataFlow Diagram) 


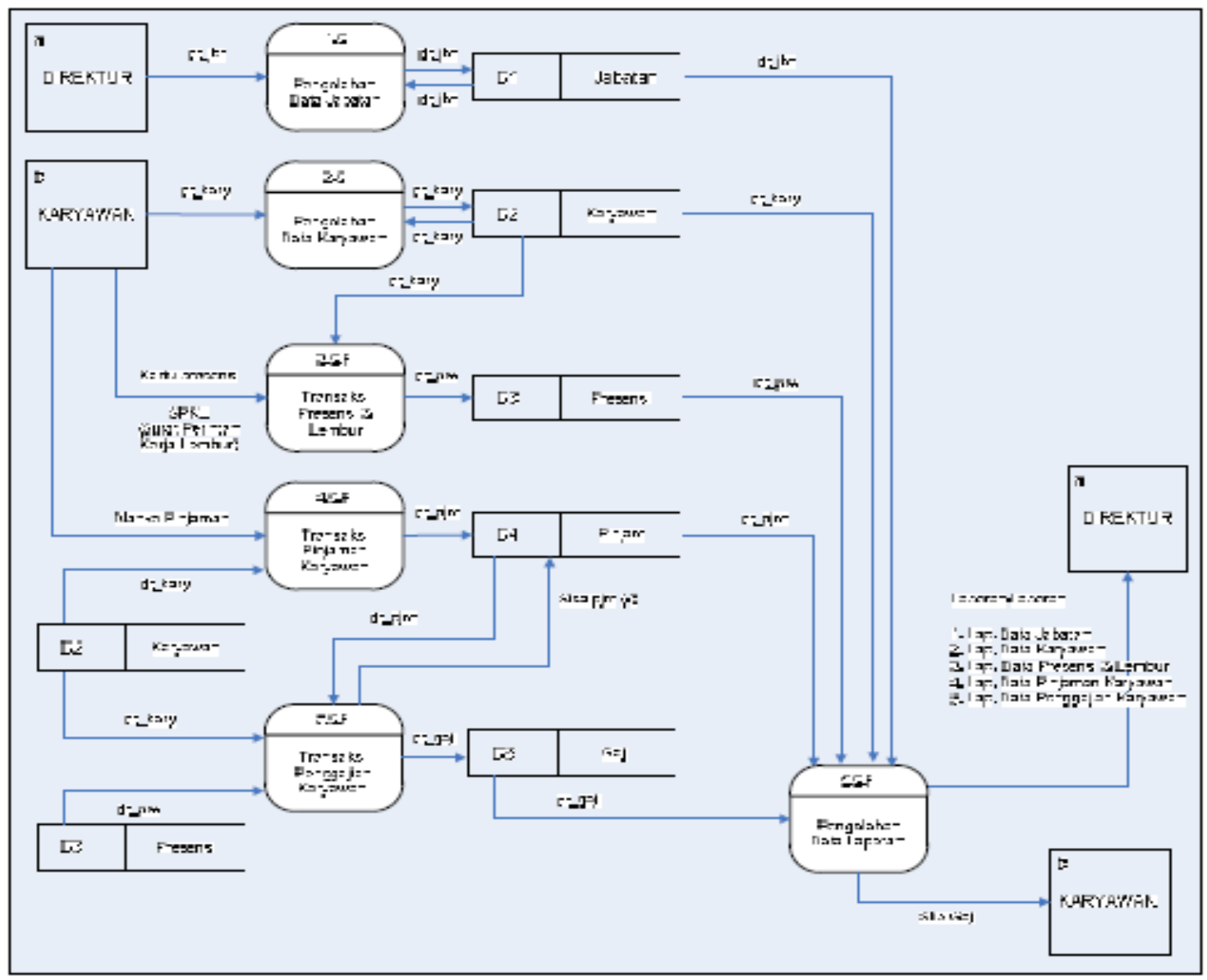

Gambar 3. Diagram Arus Data (Data Flow Diagram) Level 0

\section{Diagram Arus Data Level 1 Proses 1 (Pengolahan Data Jabatan)}

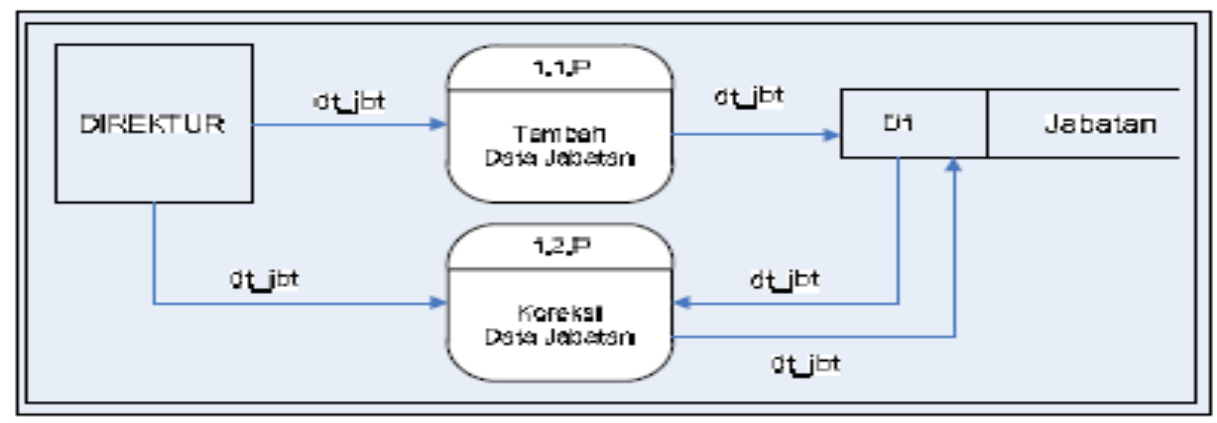

Gambar 4. Diagram Arus Data Level 1 Proses 1

Diagram Arus Data Level 1 Proses 2 (Pengolahan Data Karyawan)

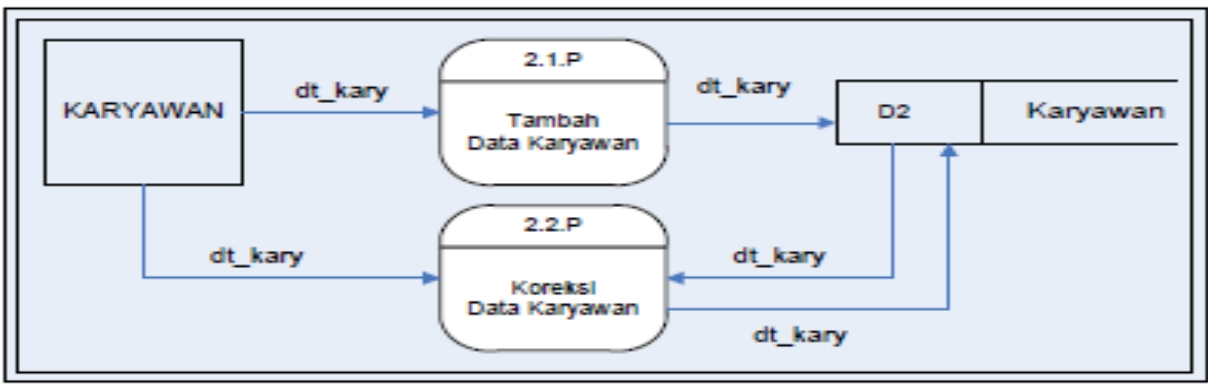

Gambar 5. Diagram Arus Data Level 1 Proses 2 
Diagram Arus Data Level 1 Proses 3 (Transaksi Presensi \& Lembur)

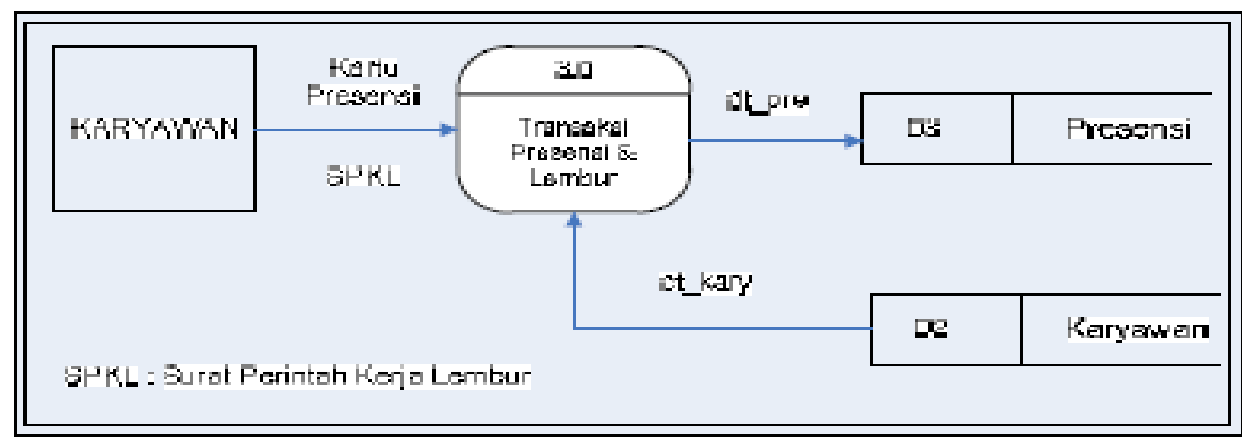

Gambar 6. Diagram Arus Data Level 1 Proses 3 (Transaksi Presensi \& Lembur

Diagram Arus Data Level 1 Proses 4 (Transaksi Pinjaman Karyawan)

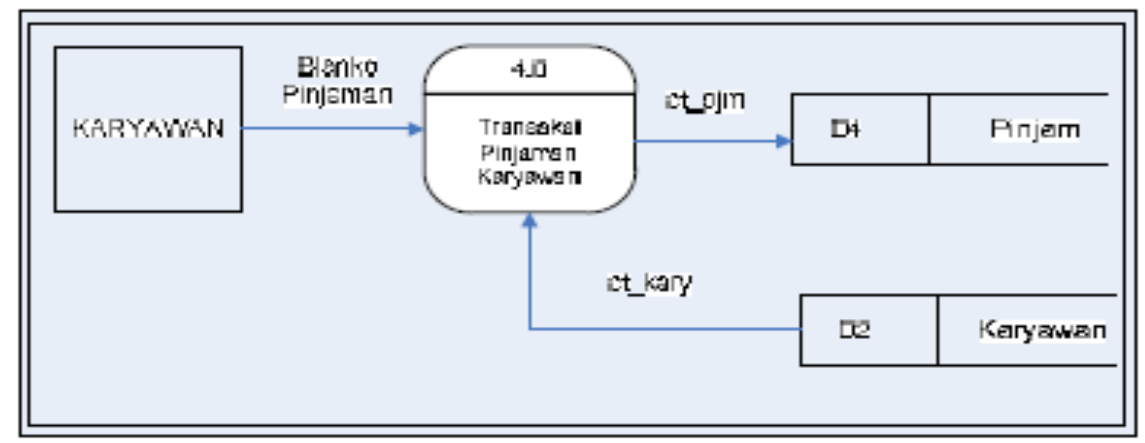

Gambar 7. Diagram Arus Data Level 1 Proses 4 (Transaksi Pinjaman Karyawan)

Diagram Arus Data Level 1 Proses 5 (Transaksi Penggajian Karyawan)

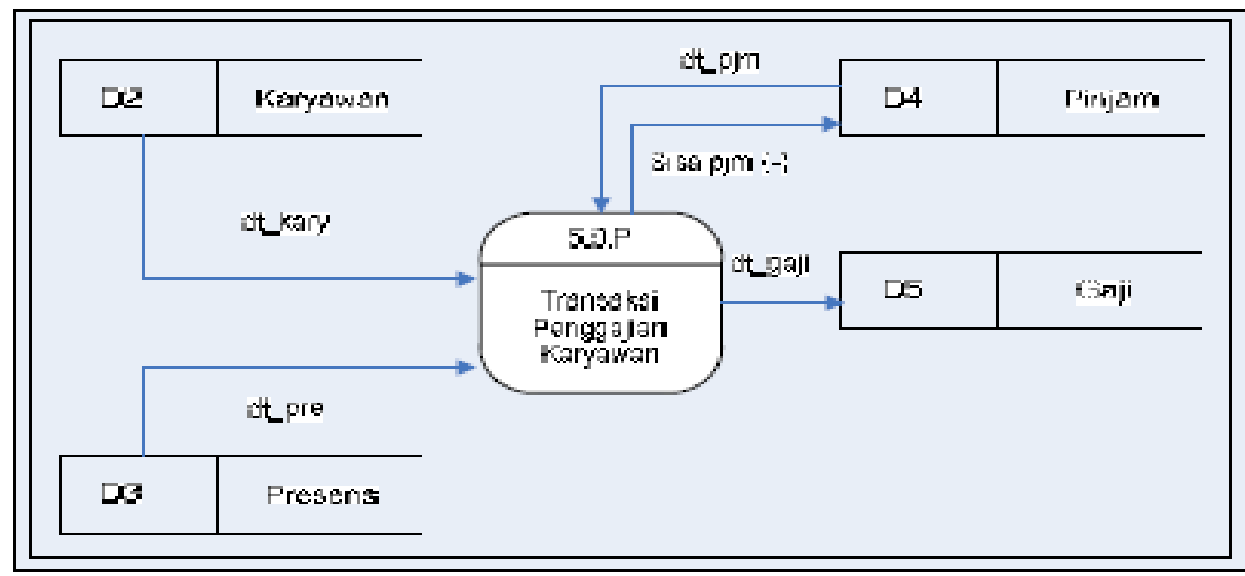

Gambar 8. Diagram Arus Data Leve1 1 Proses 5 
Diagram Arus Data Level 1 Proses 6 (Pengolahan Data Laporan)

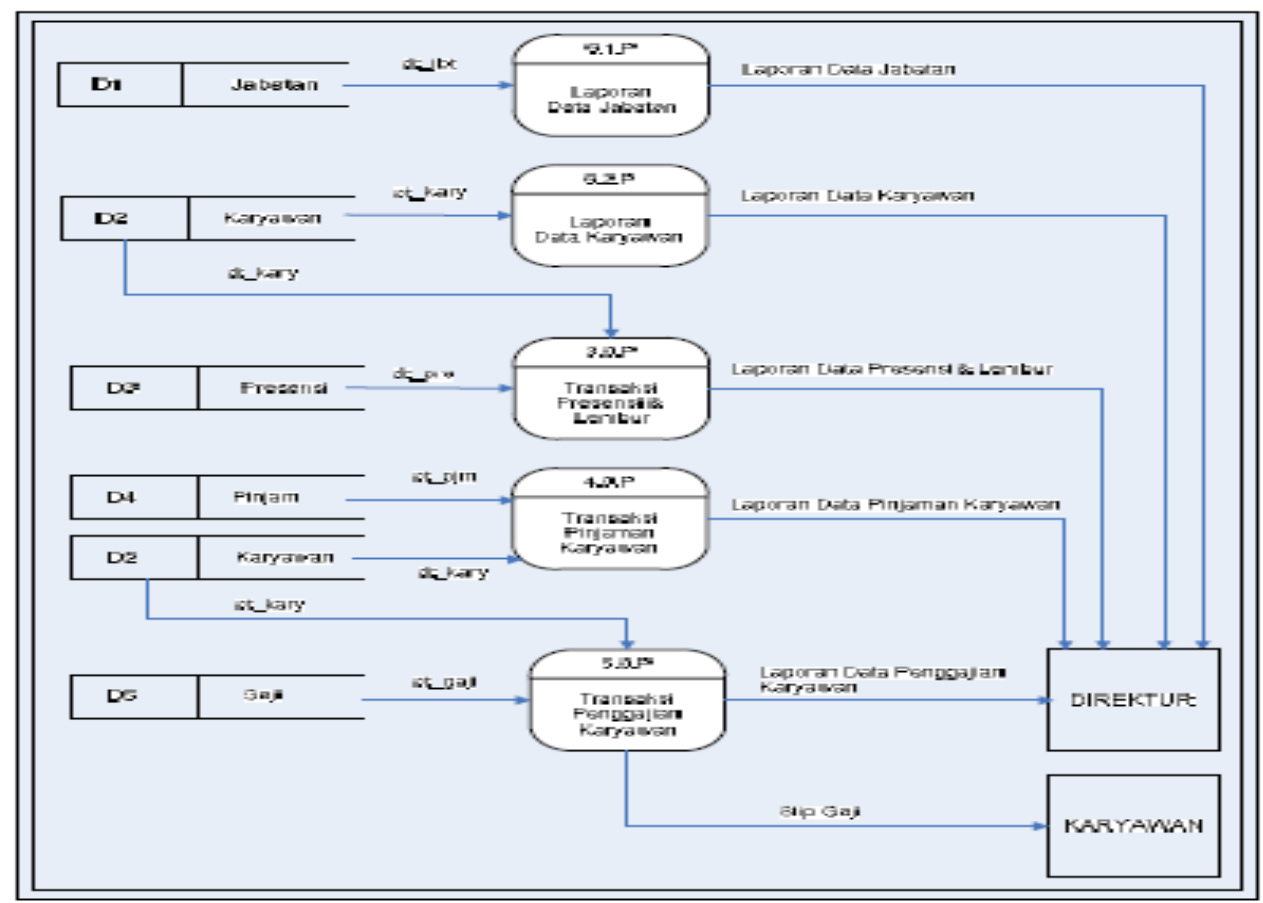

Gambar 9. Diagram Arus Data Level 1 Proses 6

Entity Relationship Diagram (ERD)

ER Diagram Pencatatan Data Karyawan

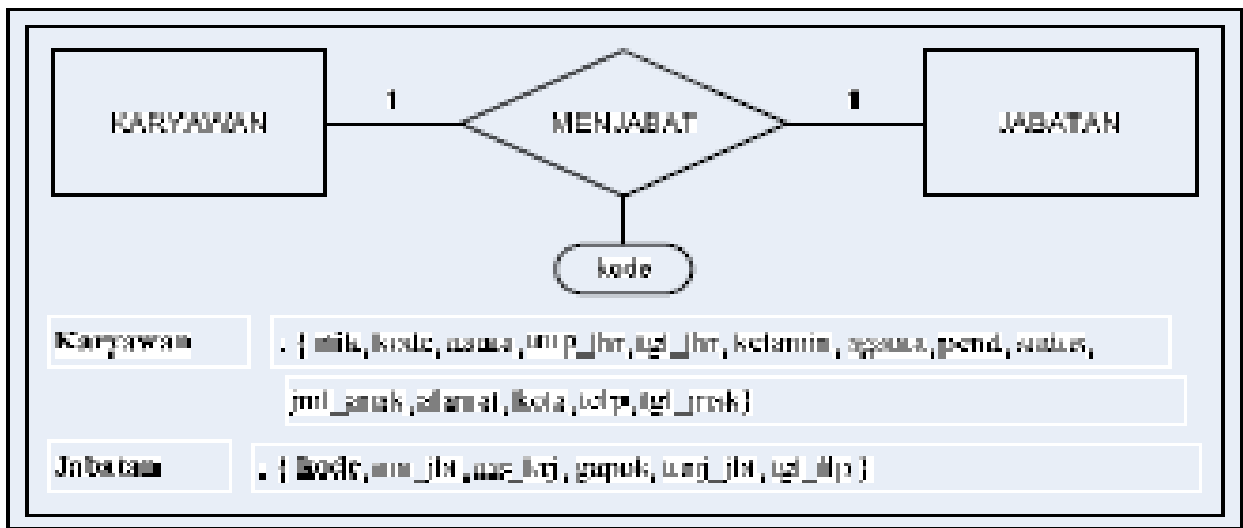

Gambar 10. ER Diagram Tabel Karyawan dan Tabel Jabatan

ER Diagram Pencatatan Data Presensi Karyawan 


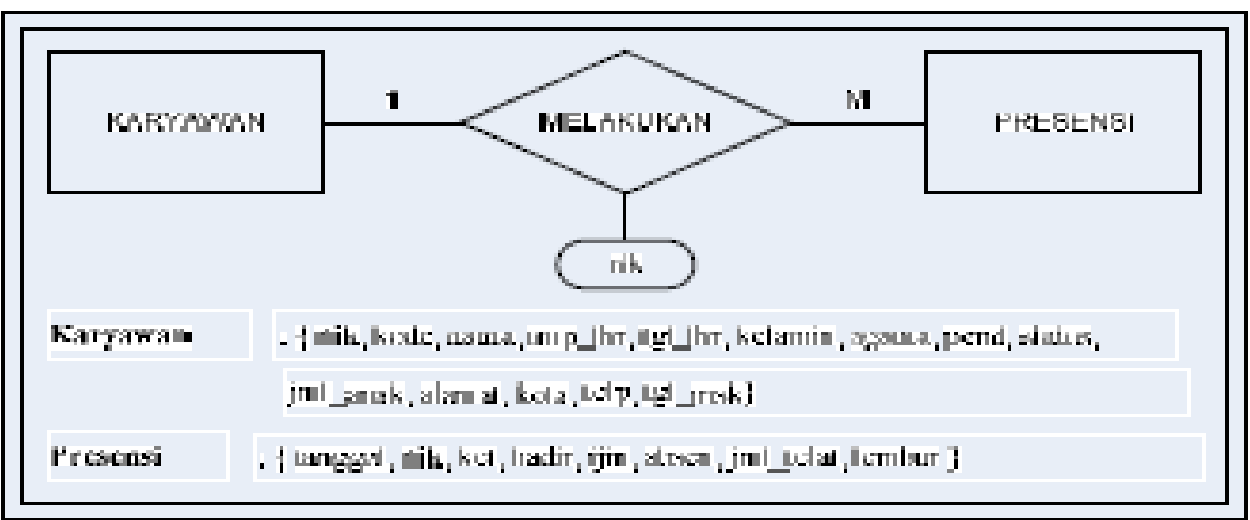

Gambar 11. ER Diagram Pencatatan Data Presensi Karyawan

\section{ER Diagram Pencatatan Data Pinjaman Karyawan}

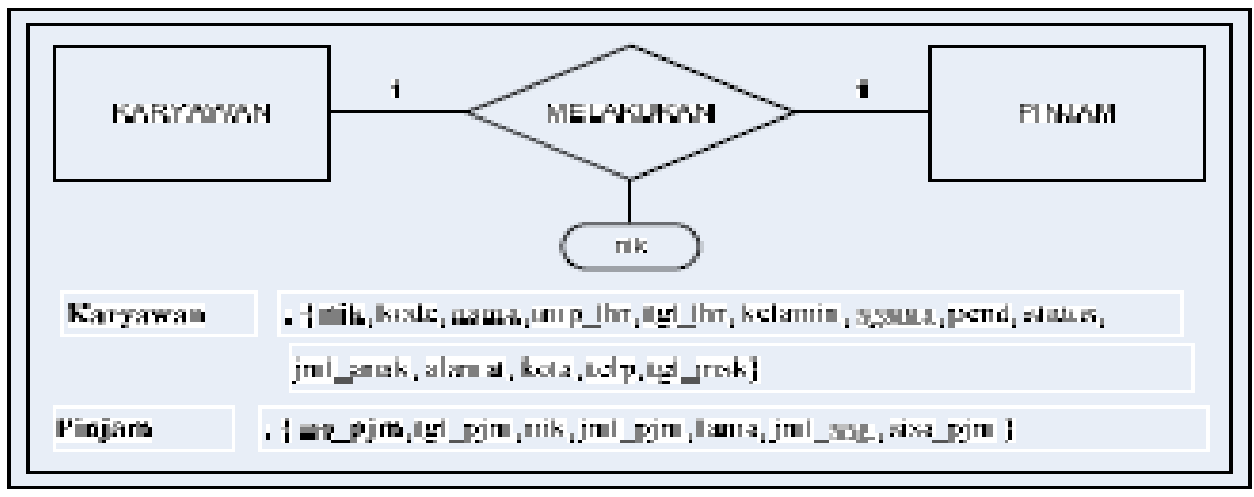

Gambar 12. ER Diagram Pencatatan Data Pinjaman Karyawan

\section{ER Diagram Pencatatan Data Penggajian Karyawan}

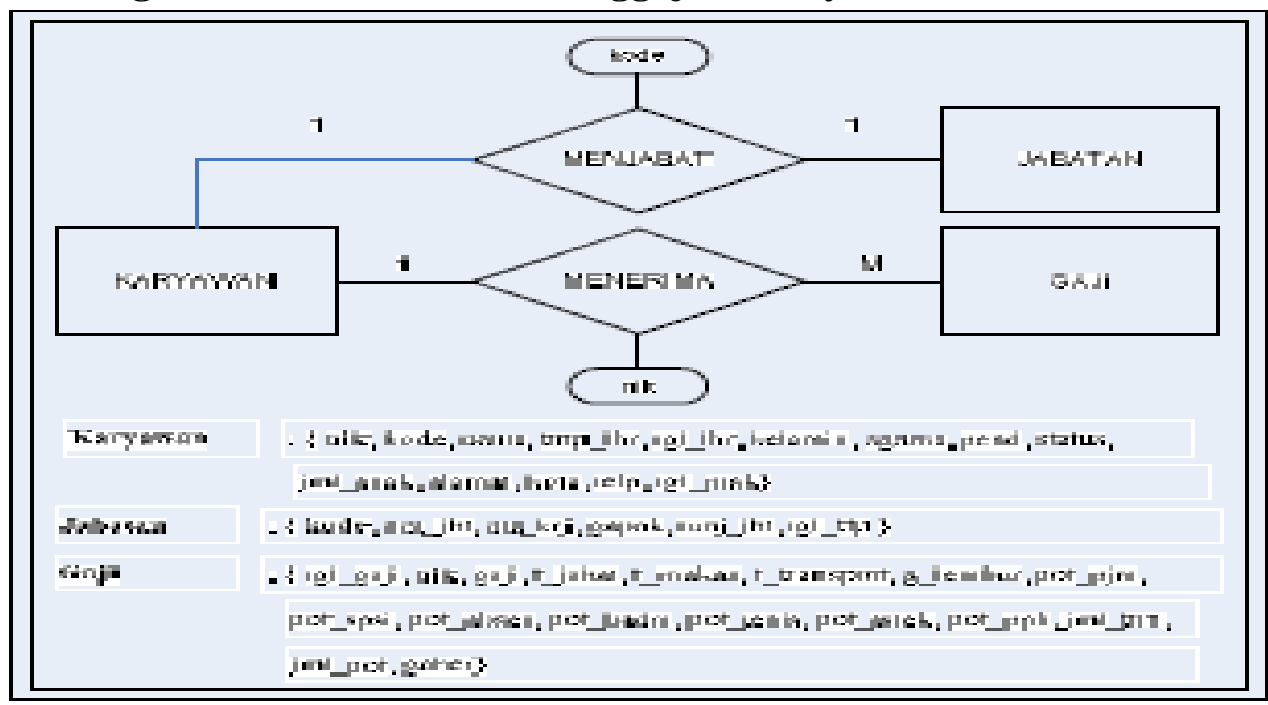

Gambar 13. ER Diagram Tabel Karyawan dan Tabel Gaji 


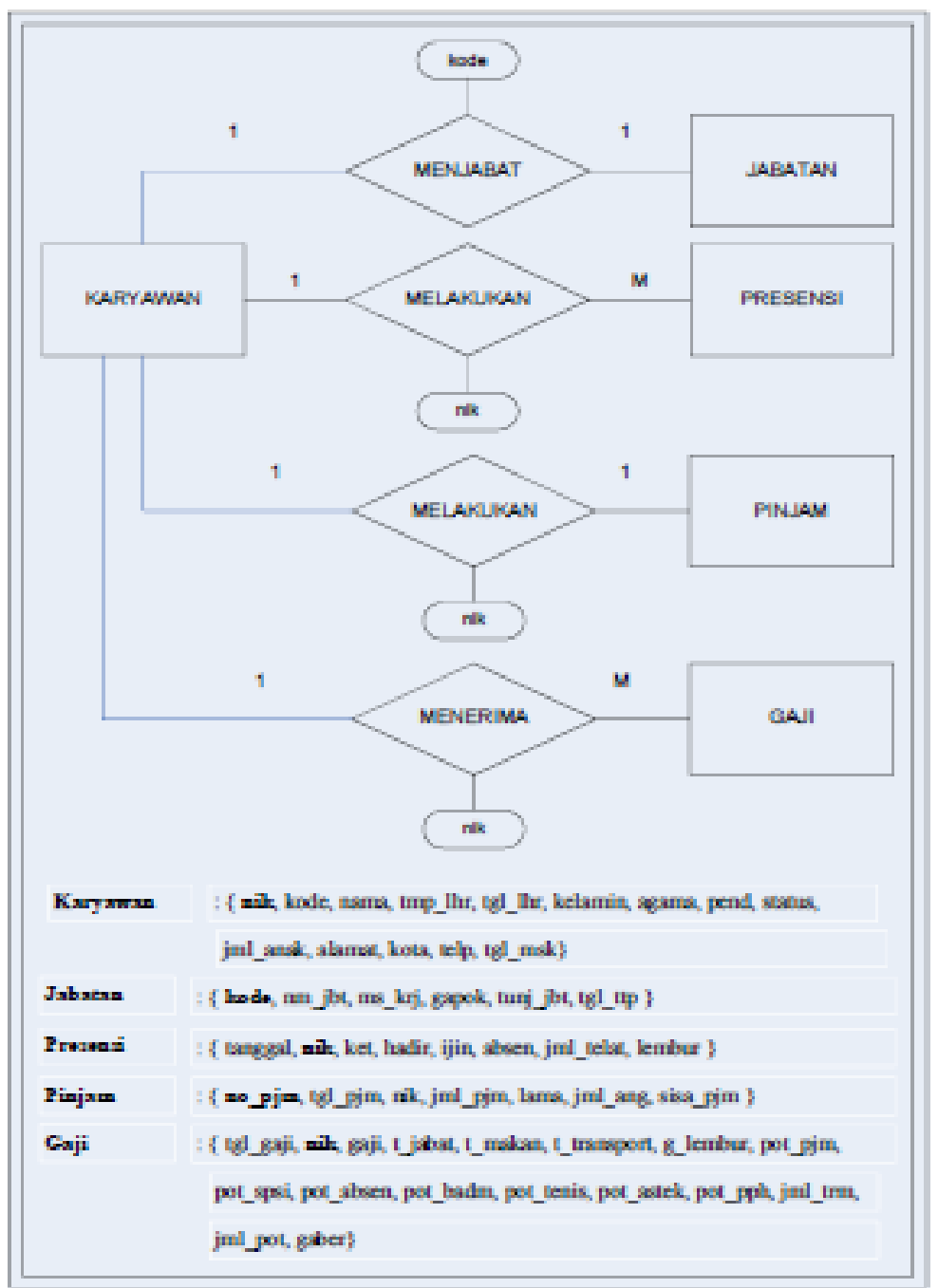

Gambar 13. Entitas Relationship Diagram Sistem Penggajian Karyawan

\section{Diagram Relasi Tabel Database}

\begin{tabular}{|c|c|c|c|c|c|c|c|}
\hline \multicolumn{2}{|l|}{ IIII jabotan } & \multicolumn{2}{|c|}{ AII karpauran } & \multicolumn{2}{|l|}{ IIII pinjam } & \multicolumn{2}{|l|}{ 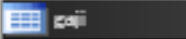 } \\
\hline 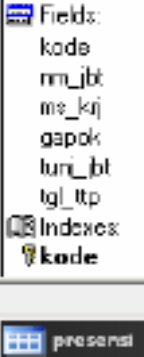 & - & $\begin{array}{l}\text { Fields } \\
\text { nik. } \\
\text { kods } \\
\text { nama } \\
\text { tmp_ltr } \\
\text { td_hr } \\
\text { kelarrin } \\
\text { agama } \\
\text { pend } \\
\text { status } \\
\text { iml_andk } \\
\text { alanst }\end{array}$ & 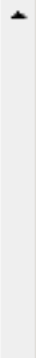 & $\begin{array}{l}\text { Ficlds } \\
\text { no_fim } \\
\text { to_pim } \\
\text { rik. } \\
\text { inl_fim } \\
\text { lams } \\
\text { inl_ang } \\
\text { gisa_pin } \\
\text { lail ndexes: } \\
\text { rik. } \\
\text { ino_pim }\end{array}$ & - & 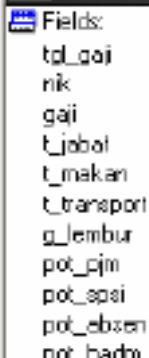 & 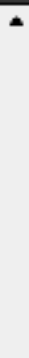 \\
\hline $\begin{array}{l}\text { 国 Fieids: } \\
\text { tanggal } \\
\text { rik } \\
\text { ket } \\
\text { hadi } \\
\text { in } \\
\text { disen } \\
\text { initelat } \\
\text { lembix }\end{array}$ & - & $\begin{array}{l}\text { kola } \\
\text { telp } \\
\text { to_msk } \\
\text { Calndexes: } \\
\text { kode } \\
\text { inik }\end{array}$ & & & & 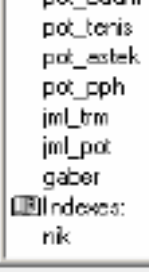 & $\nabla$ \\
\hline $\begin{array}{l}\text { Calndexex } \\
\text { rik }\end{array}$ & T & & & & & & \\
\hline
\end{tabular}


Gambar 14. Relasi Antar Tabel Sistem Informasi Penggajian Karyawan

Kamus Data (Data Dictionary)

Kamus Data Tabel Jabatan

Tabel 2. Kamus Data Tabel Jabatan

\begin{tabular}{|c|l|l|c|c|c|l|}
\hline \multirow{2}{*}{ No } & \multicolumn{2}{|c|}{ Nama Item Data } & \multirow{2}{*}{ Type } & \multirow{2}{*}{ Lebar } & \multirow{2}{*}{ Pict } & \multirow{2}{*}{ Keterangan } \\
\cline { 2 - 3 } & \multicolumn{1}{|c|}{ Di Sistem } & Di Program & & & & \\
\hline \hline 1 & Kode Jabatan & Kode & $\mathrm{C}$ & 5 & $\mathrm{X}(5)$ & Kode Jabatan \\
\hline 2 & Nama Jabatan & Nm_jbt & $\mathrm{C}$ & 25 & $\mathrm{X}(25)$ & Nama Jabatan \\
\hline 3 & Masa Kerja & Ms_krj & $\mathrm{C}$ & 10 & $\mathrm{X}(10)$ & Masa Kerja \\
\hline 4 & Gaji Pokok & Gapok & $\mathrm{N}$ & 7 & $\mathrm{X}(7)$ & Gaji Pokok \\
\hline 5 & Tunj. Jabatan & Tunj_jbt & $\mathrm{N}$ & 6 & $\mathrm{X}(6)$ & Tunj. Jabatan \\
\hline 6 & Tanggal Penetapan & Tg1_ttp & $\mathrm{D}$ & 8 & $\mathrm{dd} / \mathrm{mm} / \mathrm{yy}$ & Tanggal Penetapan \\
\hline
\end{tabular}

\section{Kamus Data Tabel Karyawan}

Tabel 3. Kamus Data Tabel Karyawan

\begin{tabular}{|c|l|l|c|c|c|l|}
\hline \multirow{2}{*}{ No } & \multicolumn{2}{|c|}{ Nama Item Data } & \multirow{2}{*}{ Type } & \multirow{2}{*}{ Lebar } & \multirow{2}{*}{ Pict } & \multirow{2}{*}{ Keterangan } \\
\cline { 2 - 6 } & \multicolumn{1}{|c|}{ Di Sistem } & Di Program & & & & \\
\hline \hline 1 & No. Induk & Nik & C & 10 & X(10) & No. Induk \\
\hline 2 & Kode & Kode & C & 5 & X(5) & Kode Jabatan \\
\hline 3 & Nama Karyawan & Nama & C & 30 & X(30) & Nama Karyawan \\
\hline 4 & Tempat Lahir & Tmp_lhr & C & 15 & X(15) & Tempat Lahir \\
\hline 5 & Tanggal Lahir & Tgl_lhr & D & 8 & dd/mm/yy & Tanggal Lahir \\
\hline 6 & Kelamin & Kel & C & 1 & 10 & Jns. Kelamin \\
\hline 7 & Agama & Agama & C & 1 & 10 & Agama \\
\hline 8 & Pendidikan & Pend & C & 1 & 20 & Pendidikan \\
\hline 9 & Status & Status & C & 1 & 10 & Perkawinan \\
\hline 10 & Jml Anak & Anak & N & 1 & & Jml Anak \\
\hline 11 & Alamat & Alamat & C & 30 & X(30) & Alamat \\
\hline 12 & Kota & Kota & C & 15 & X(15) & Kota \\
\hline 13 & No. Telepon & Telp & C & 12 & X(12) & No. Telepon \\
\hline 14 & Tg1 Masuk & Tgl_msk & D & 8 & dd/mm/yy & Tgl Masuk \\
\hline
\end{tabular}

Kamus Data Tabel Presensi

Tabel 4. Kamus Data Tabel Presensi

\begin{tabular}{|c|l|l|c|c|c|l|}
\hline \multirow{2}{*}{ No } & \multicolumn{2}{|c|}{ Nama Item Data } & \multirow{2}{*}{ Type } & \multirow{2}{*}{ Lebar } & \multirow{2}{*}{ Pict } & \multirow{2}{*}{ Keterangan } \\
\cline { 2 - 3 } & \multicolumn{1}{|c|}{ Di Sistem } & Di Program & & & & \\
\hline \hline 1 & Tgl Presensi & Tanggal & D & 8 & dd/mm/yy & Tgl.Presensi \\
\hline 2 & No. Induk & Nik & C & 10 & $\mathrm{X}(10)$ & No. Induk \\
\hline 3 & Keterangan & Ket & C & 5 & X(5) & Keterangan \\
\hline 4 & Jumlah Hadir & Hadir & N & 2 & $9(2)$ & Jumlah Hadir \\
\hline 5 & Jumlah Ijin & Ijin & N & 2 & $9(2)$ & Jumlah Ijin \\
\hline 6 & Jumlah Absen & Absen & N & 2 & $9(2)$ & Jumlah Absen \\
\hline 7 & Jumlah Terlambat & Jml_telat & N & 4 & $9(4)$ & Jumlah Terlambat \\
\hline 8 & Jumlah Lembur & Lembur & N & 2 & $9(2)$ & Jumlah Lembur \\
\hline
\end{tabular}

Kamus Data Tabel Pinjam 
Tabel 5. Kamus Data Tabel Pinjam

\begin{tabular}{|c|l|l|c|c|c|l|}
\hline \multirow{2}{*}{ No } & \multicolumn{2}{|c|}{ Nama Item Data } & \multirow{2}{*}{ Type } & \multirow{2}{*}{ Lebar } & \multirow{2}{*}{ Pict } & \multirow{2}{*}{ Keterangan } \\
\cline { 2 - 3 } & \multicolumn{1}{|c|}{ Di Sistem } & Di Program & & & & \\
\hline \hline 1 & Tgl. Pinjam & Tg1_pjm & D & 8 & dd/mm/yy & Tgl. Pinjam \\
\hline 2 & No. Pinjam & No_pjm & C & 10 & $\mathrm{X}(10)$ & No. Pinjam \\
\hline 3 & No. Induk & Nik & C & 10 & $\mathrm{X}(10)$ & No. Induk \\
\hline 4 & Jumlah Pinjam & Jml_pjm & N & 7 & $9(7)$ & Jumlah Pinjam \\
\hline 5 & Lama Angsur & Lama & N & 2 & $9(2)$ & Lama Angsur \\
\hline 6 & Jml. Angsuran & Jml_ang & N & 6 & $9(6)$ & Jml. Angsuran \\
\hline 7 & Sisa Pinjaman & Sisa_pjm & N & 7 & $9(7)$ & Sisa Pinjaman \\
\hline
\end{tabular}

\section{Kamus Data Tabel Gaji}

Tabel 6. Kamus Data Tabel Gaji

\begin{tabular}{|c|l|l|c|c|c|l|}
\hline \multirow{2}{*}{ No } & \multicolumn{2}{|c|}{ Nama Item Data } & \multirow{2}{*}{ Type } & \multirow{2}{*}{ Lebar } & \multirow{2}{*}{ Pict } & \multirow{2}{*}{ Keterangan } \\
\cline { 2 - 3 } & \multicolumn{1}{|c|}{ Di Sistem } & Di Program & & & & \\
\hline \hline 1 & Tanggal Gaji & Tg1_gaji & D & 8 & dd/mm/yy & Tanggal Gaji \\
\hline 2 & No. Induk & Nik & C & 10 & X(10) & No. Induk \\
\hline 3 & Gaji Pokok & Gaji & N & 7 & $9(7)$ & Gaji Pokok \\
\hline 4 & Tunj. Jabatan & T_jabat & N & 6 & $9(6)$ & Tunj. Jabatan \\
\hline 5 & Tunj. Makan & T_makan & N & 6 & $9(6)$ & Tunj. Makan \\
\hline 6 & Tunj. Transport & T_transport & N & 6 & $9(6)$ & Tunj. Transport \\
\hline 7 & Gaji Lembur & G_lembur & N & 6 & $9(6)$ & Gaji Lembur \\
\hline 8 & Pot. Pinjaman & Pot_pjm & N & 6 & $9(6)$ & Pot. Pinjaman \\
\hline 9 & Pot. SPSI & Pot_spsi & N & 6 & $9(6)$ & Pot. SPSI \\
\hline 10 & Pot. Absen & Pot_absen & N & 6 & $9(6)$ & Pot. Absen \\
\hline 11 & Pot. Badminton & Pot_badm & N & 6 & $9(6)$ & Pot. Badminton \\
\hline 12 & Pot. Tenis & Pot_tenis & N & 6 & $9(6)$ & Pot. Tenis \\
\hline 13 & Pot. Astek & Pot_astek & N & 6 & $9(6)$ & Pot. Astek \\
\hline 14 & Pot. PPH 21 & Pot_pph & N & 6 & $9(6)$ & Pot. PPH 21 \\
\hline 15 & Jumlah Terima & Jml_trm & N & 7 & $9(7)$ & Jumlah Terima \\
\hline 16 & Jml. Potongan & Jm1_pot & N & 7 & $9(7)$ & Jml. Potongan \\
\hline 17 & Gaji Bersih & Gaber & N & 7 & $9(7)$ & Gaji Bersih \\
\hline
\end{tabular}

\section{Desain Output Data Slip Gaji Karyawan}




\begin{tabular}{|c|c|c|c|}
\hline \multicolumn{4}{|l|}{ SLLP GAJI } \\
\hline \multicolumn{4}{|c|}{ PT. BAIIK UAINARHALA SURAKAHIA } \\
\hline GAIL BULANN & \multicolumn{2}{|c|}{$: x \times x \times x \times 60 x x \times x \times x$} & : dd-111m-ryry \\
\hline N I K & \multicolumn{3}{|l|}{; $x \operatorname{cox} \times \times \times x \times 0 x$} \\
\hline$N A M A$ & \multicolumn{3}{|c|}{ 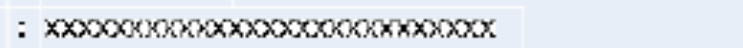 } \\
\hline JABATANA & \multicolumn{3}{|c|}{ 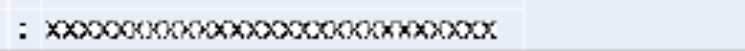 } \\
\hline \multicolumn{2}{|c|}{ PENEFIMAAN } & \multicolumn{2}{|c|}{ PENEFIMAAIN } \\
\hline Gaji Pokdk & 3.459.459:29 & Pot, Pinjoman & 40909209 \\
\hline T. Jabatan & 259.229.29 & Pot SHSi & 459059.09 \\
\hline T. Makanl & 499.299 .29 & Pot. Absen & 499.399 .09 \\
\hline T. Transport & 499.209 .29 & Pot Badminton & 099.499 .09 \\
\hline \multirow[t]{3}{*}{ Gaji Lembur } & 499.299.29 & Pot. Teris & 229.429 .29 \\
\hline & & Pot Astek & 099.459 .59 \\
\hline & & $\mathbf{P F H} 2 \mathbf{1}$ & 099.459 .09 \\
\hline \multirow[t]{2}{*}{ Jml. Terima } & 3.459,459.29 & Jml. Potongen & 459059.09 \\
\hline & \multicolumn{2}{|c|}{ GAJI UERSLH } & 3it59iogas \\
\hline \multicolumn{2}{|c|}{$(x \times x \times x \times x \times x \times x \times x \times x \times x \times 1 \times x)$} & \multicolumn{2}{|c|}{ (EAG. KEUANGANA) } \\
\hline
\end{tabular}

\section{Gambar 15. Desain Output Slip Gaji Karyawan}

\section{Skema Jaringan Multi User}

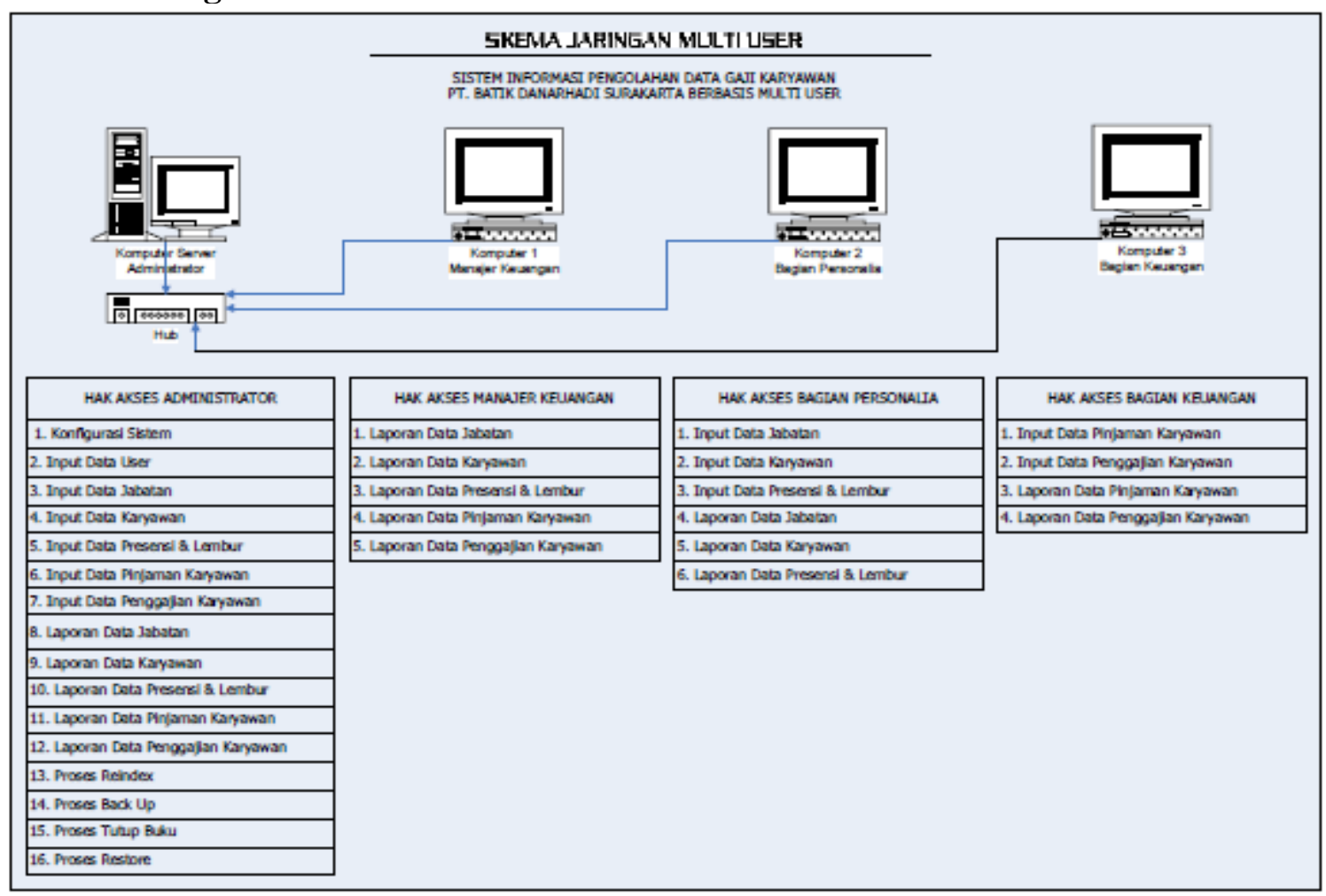

Gambar 16. Skema Jaringan Multi User Sistem Penggajian 


\section{Implementasi Program}
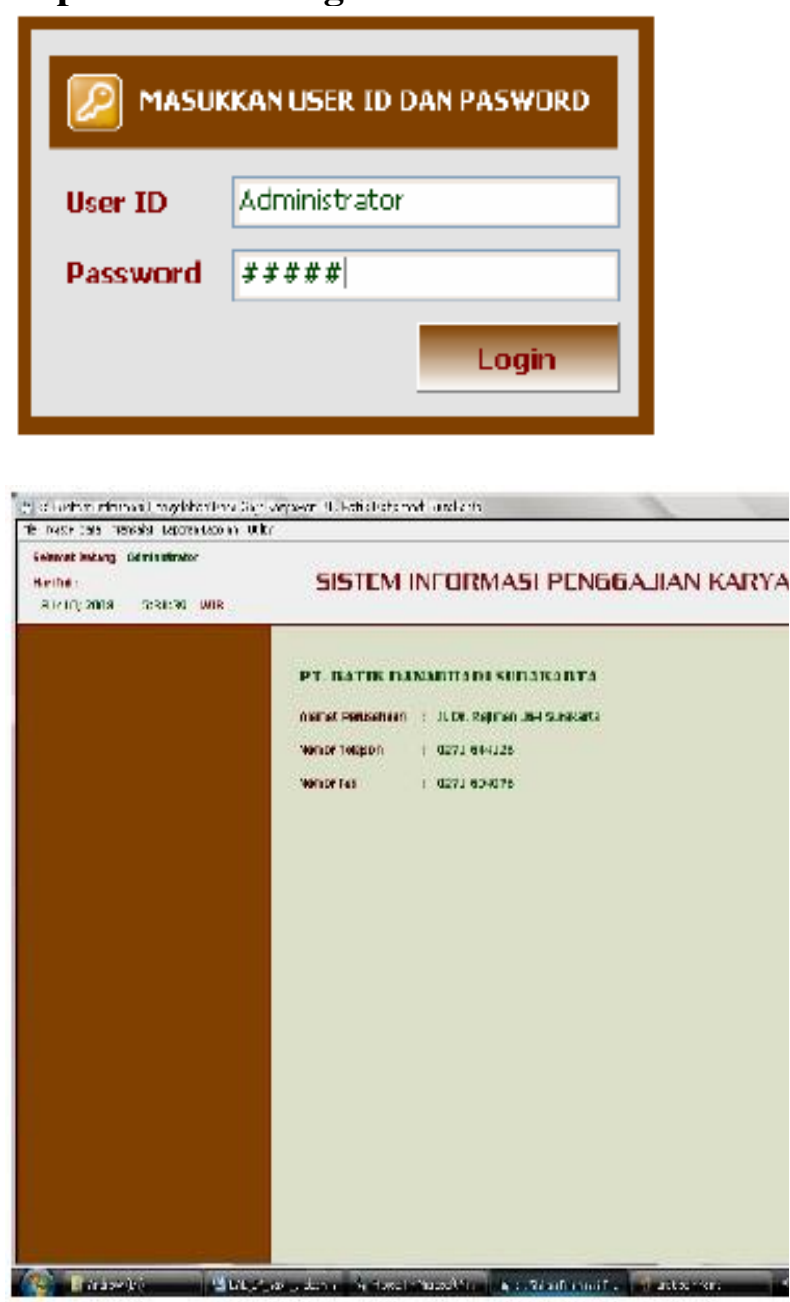

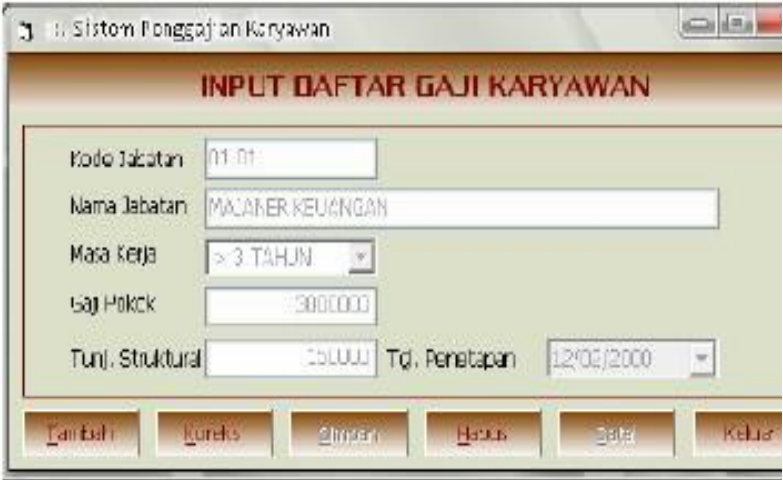
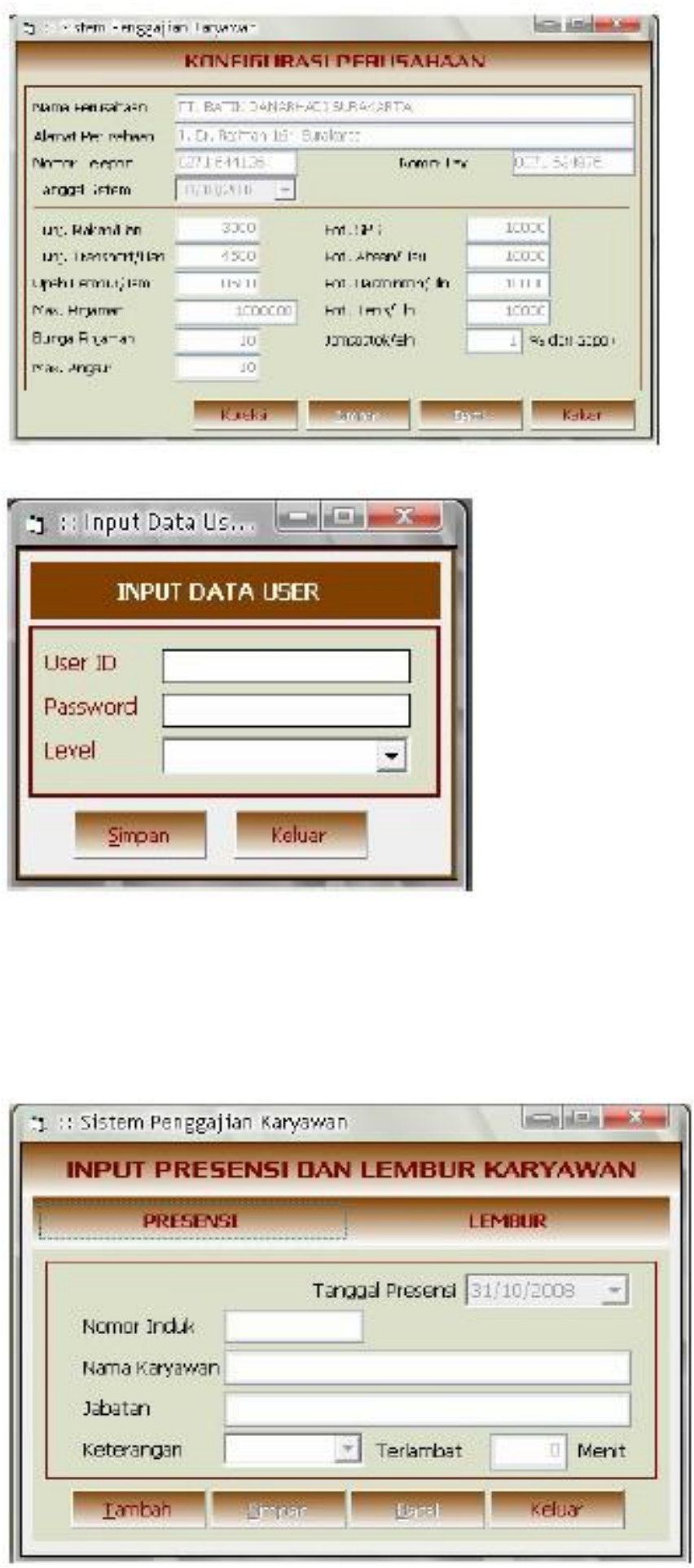

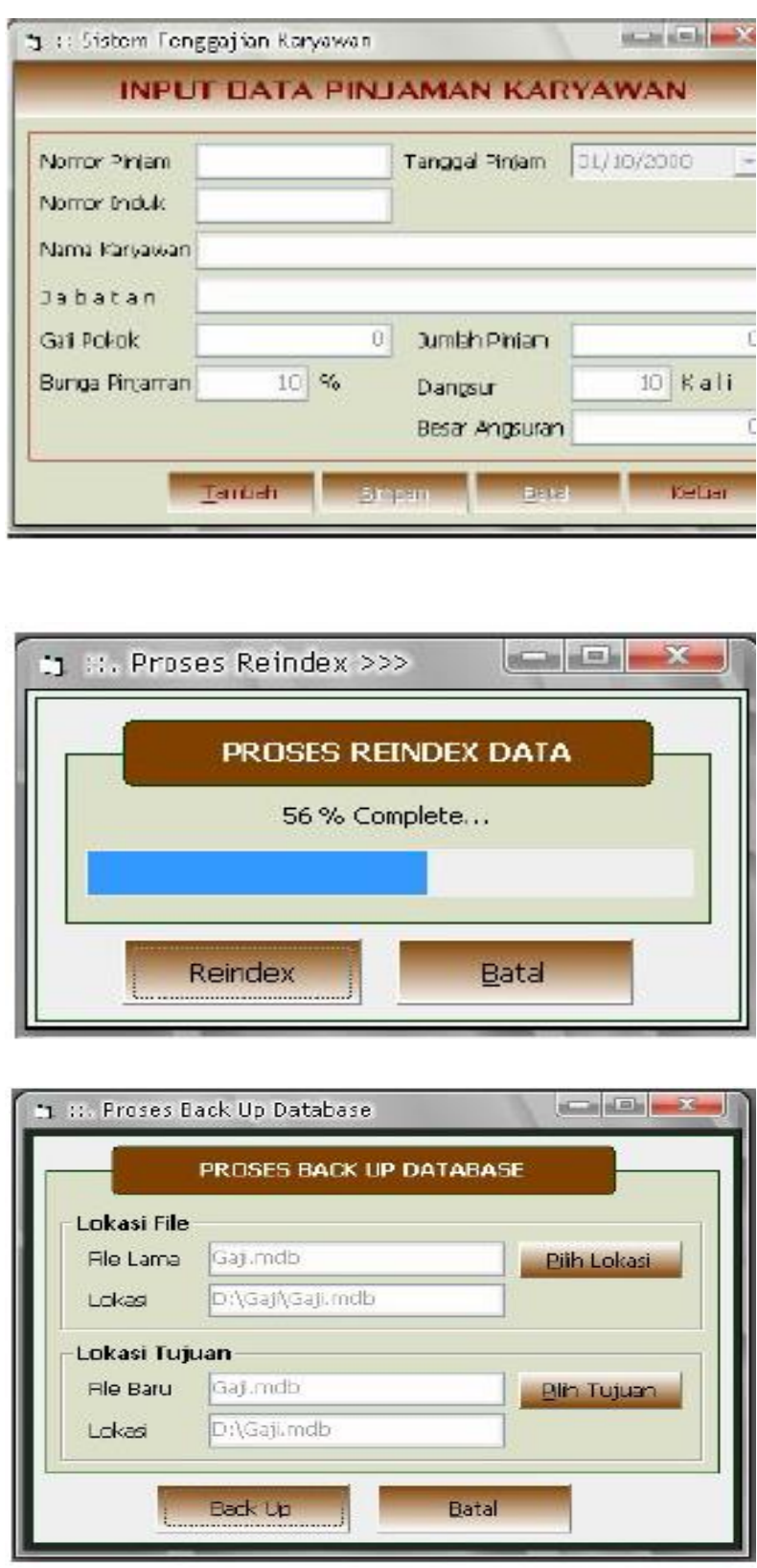

\section{Kesimpulan}

Berdasarkan uraian permasalahan dan pembahasan pada bab sebelumnya tentang penyusunan skripsi Sistem Informasi Pengolahan Data Gaji Karyawan pada PT. Batik Danarhadi Surakarta ini disusun berdasarkan perancangan sistem yang terdiri dari Diagram Konteks (Context Diagram), Hierarchy Input Proses Output (HIPO), Diagram Arus Data (DAD), Entity Relationship Diagram (ERD), Desain Kamus Data, Desain Input dan Desain Output. Perancangan sistem yang dibahas
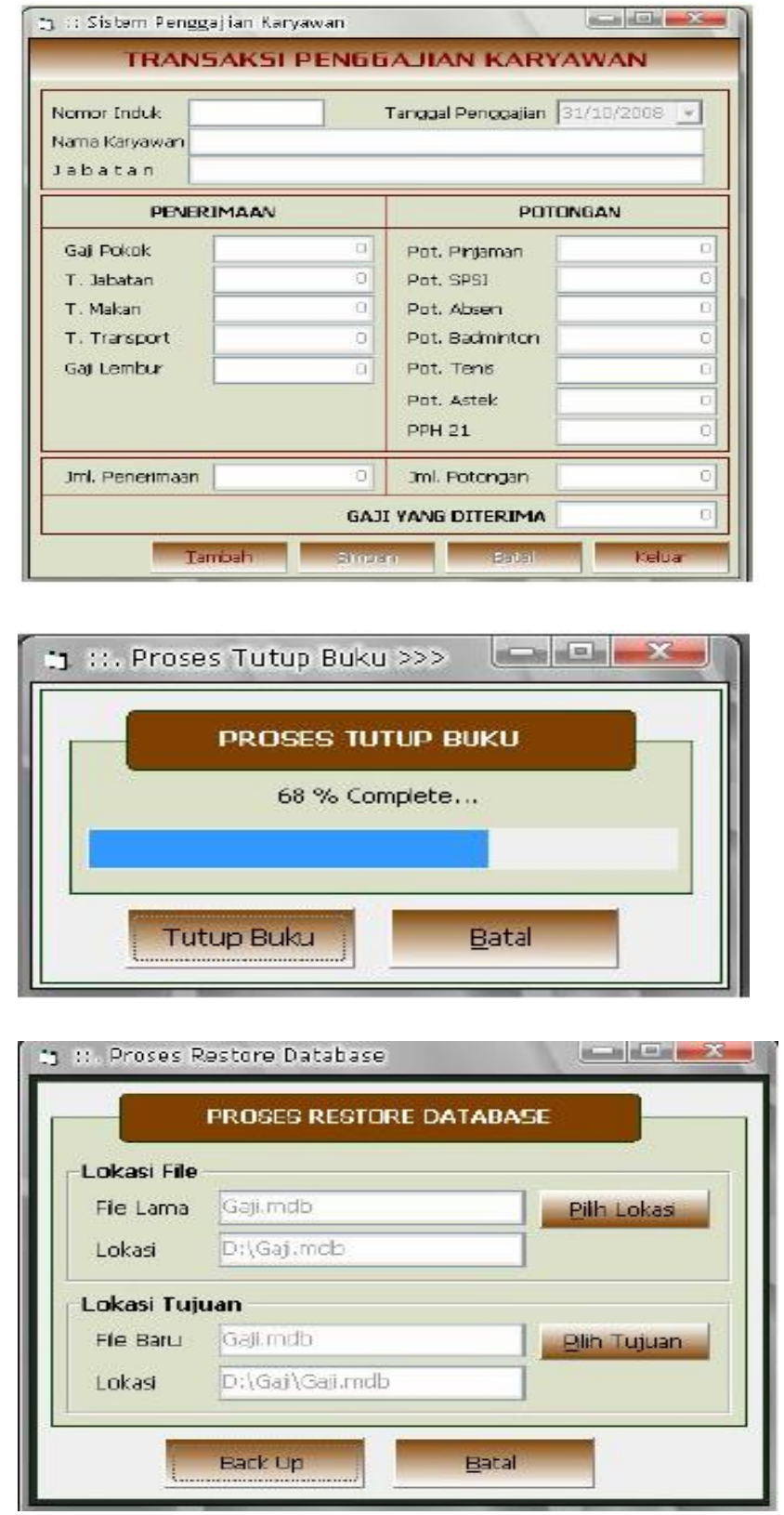

tersebut menggunakan alat bantu berupa komputer yang menghasilkan suatu sistem yang dapat digunakan sebagai salah satu dalam pemrosesan data yaitu pengolahan data gaji karyawan secara multi user.

Pada Sistem Informasi Pengolahan Data Gaji Karyawan pada PT.

Batik Danarhadi Surakarta terdiri dari beberapa menu, antara lain:

1. Set Up, terdiri dari beberapa sub menu:

a. Konfigurasi Sistem

b. Input Data User

c. Exit 
2. Master, terdiri dari beberapa sub menu:

a. Input Data Jabatan

b. Input Data Karyawan

3. Transaksi. Terdiri dari beberapa sub menu:

a. Transaksi Presensi dan Lembur

b. Transaksi Pinjaman Karyawan

c. Transaksi Penggajian Karyawan

4. Laporan, terdiri dari beberapa sub menu:

a. Laporan Data Jabatan

b. Laporan Data Karyawan

c. Laporan Data Presensi dan Lembur

d. Laporan Data Pinjaman Karyawan

e. Laporan Data Penggajian Karyawan, terdiri dari rekap gaji

karyawan dan slip gaji.

5. Utility, terdiri dari beberapa sub menu:

a. Proses Reindex

b. Proses Back Up

c. Proses Tutup Buku

d. Proses Restore

Pada Sistem Informasi Pengolahan Data Gaji Karyawan pada PT. Batik Danarhadi Surakarta menggunakan database (*.mdb), yaitu Gaji.mdb,yang terdiri dari beberapa tabel antara lain : jabatan, karyawan, presensi, pinjam dan gaji.

\section{Daftar Pustaka}

Ario Suryo Kusumo, Drs., Pemrograman

Database Dengan Visual Basic 6.0.
Elex Media Komputindo, Jakarta, 2000

Hartono, Jogianto, MBA, AKT, PH.D, Pengenalan Komputer, Dasar Ilmu Komputer, Pemrograman, Sistem Informasi dan Intelegensi Buatan. Edisi III, Yogyakarta, Andi, 2002

Jogiyanto. HM, Analisa dan desain Sistem Informasi Pendekatan Terstruktur Teori Aplikasi Bisnis. Andi Offset, Yogyakarta 2005.

Moenir, Ardianto ; Yulianto, Fajar. Perancangan Sistem Informasi Penggajian Berbasis Web Dengan Metode Waterfall Pada PT. Sinar Metrindo Perkasa (Simetri). Jurnal Informatika Universitas Pamulang 127 Vol. 2, No. 3, September 2017.

Raymond Mcleod, Jr, Sistem Informasi Manajemen, Pearson Education Asia Pte.Ltd dan PT Prenhallindo, Jakarta, 2001 Retna Prasetia dan catur Edi Widodo, Interfacting Port Paralel dan Port Serial Komputer dengan Visual Basic 6.0, Andi, Yogyakarta, 2004

Tatang M Amirin. Drs, Pokok-pokok Teori Sistem. Raja Grafindo Persada, 2003

Vitelius, Lusianus, Sistem Pengolahan Data Gaji Pegawai Proyek Pada CV. Karya Agung Geliting-Maumere 